\title{
Metschnikowia vanudenii sp. nov. and Metschnikowia lachancei sp. nov., from flowers and associated insects in North America
}

\author{
Gabriella Giménez-Jurado, ${ }^{1}$ Cletus P. Kurtzman, ${ }^{2}$ William T. Starmer ${ }^{3}$ \\ and Isabel Spencer-Martins ${ }^{1}$ \\ ${ }^{1}$ Centro de Recursos Microbiológicos (CREM), Biotechnology Unit, Faculty of Sciences and \\ Technology, New University of Lisbon, 2829-516 Caparica, Portugal \\ ${ }^{2}$ National Center for Agricultural Utilization Research, Agricultural Research Service, US \\ Department of Agriculture, Peoria, IL 61604, USA \\ ${ }^{3}$ Department of Biology, Syracuse University, NY 13244, USA
}

\begin{abstract}
Two new species of the ascosporic yeast genus Metschnikowia were isolated from nectaries and associated muscoid flies of flowers from the common milkweed (Asclepias syriaca) in North America, and are described as Metschnikowia vanudenii [type strain $=\mathrm{PYCC} 4650^{\top}=\mathrm{CBS}$ $9134^{\top}=$ NRRL $\mathrm{Y}-27243^{\top}=\mathrm{UWO}(\mathrm{PS}) 86 \mathrm{~A} 4.1^{\top}$ ] and Metschnikowia lachancei $[$ type strain $=$ PYCC $4605^{\top}=$ CBS $9131^{\top}=$ NRRL Y $\left.-27242^{\top}=U W O(P S) 7 A S B 2.3^{\top}\right]$. As with the previously described Metschnikowia gruessii, M. vanudenii has vegetative cells with an 'aeroplane' or cross-like configuration, produces ovoid chlamydospores and forms ellipsoidopedunculate asci with two acicular ascospores. Metschnikowia lachancei is distinguished from other Metschnikowia species by formation of club-shaped asci with 1-2 thick clavate ascospores. The phylogenetic positions of the proposed new species within Metschnikowia were determined from sequence analysis of the D1/D2 domain of 26S rDNA. The new species show low nuclear DNA relatedness with neighbouring taxa.
\end{abstract}

\section{INTRODUCTION}

Metschnikowia species often thrive in insect-flower ecosystems where they proliferate owing to the high sugar concentration of the nectar. The sugar composition of floral nectar varies among plant species, but shows a predominance of hexoses (glucose and fructose) and the disaccharide sucrose. Several recently described Metschnikowia species (Hong et al., 2001; Kurtzman \& Droby, 2001; Lachance et al., 2001a, b; Lachance \& Bowles, 2002) add to the abundance of flower-associated species over those of aquatic origin, suggesting that the proliferation of terrestrial flowering plants and associated insects has markedly impacted genetic diversification in Metschnikowia. The large number of nucleotide substitutions among Metschnikowia species in the D1/D2 domain of large subunit rDNA, especially among the large-spored species, further supports the idea that the genus is highly diverged and that there are numerous undetected species.

Published online ahead of print on 11 April 2003 as DOI 10.1099/ ijs.0.02470-0.

Abbreviation: nDNA, nuclear DNA.

The GenBank accession numbers for the D1/D2 26S rDNA sequences of strain PYCC $4650^{\top}$ and PYCC $4605^{\top}$ are AF017404 and AY080995, respectively.
In the present study, two novel species of Metschnikowia are proposed. These species, to be named Metschnikowia vanudenii and Metschnikowia lachancei, were isolated in North America from the common milkweed Asclepias syriaca and associated insects. $M$. vanudenii shares with Metschnikowia gruessii the formation of 'aeroplane' cells, i.e. superimposed pairs of cells that form a cross-like configuration. The second species, M. lachancei, is characterized by clavate ascospores, which differentiates it from all other recognized species of Metschnikowia.

\section{METHODS}

Yeast strains. The five known strains of $M$. vanudenii were obtained from North America. The type strain of $M$. vanudenii (PYCC $4650^{\mathrm{T}}$ ) was isolated by M. A. Lachance, in 1986, from a 'walk plate' by allowing a muscoid fly collected from the common milkweed Asclepias syriaca in Guelph, Ontario, Canada, to walk over the solidified medium (Lachance et al., 2001a). The origin of the remaining four strains (PYCC 4603, PYCC 4606, PYCC 4648 and PYCC 4649) was nectar from flowers of $A$. syriaca sampled in the province of Québec, Canada. The type strain of M. lachancei (PYCC $4605^{\mathrm{T}}$ ) was isolated in 1987 from nectar of the flower A. syriaca in South Bombay, NY, USA. W. T. Starmer recovered a second strain of this species (PYCC 5767) from a flower of Calystegia sepium (hedge bindweed), in Newfound Gap, Smoky Mountains National Park, TN, USA. All strains examined in this work have been deposited 
(living and dried) in the Portuguese Yeast Culture Collection (PYCC), Monte de Caparica, Portugal, as well as in other collections, and accession numbers are given in Table 1.

Phenotypic characterization. The morphological and physiological characteristics of the strains were determined by conventional techniques described by Yarrow (1998). Sporulation was induced using the conditions recommended by Pitt \& Miller (1968).

DNA base composition and DNA-DNA reassociations. For thermal denaturation and reassociation experiments, DNA was purified by chromatography on hydroxylapatite columns following the protocol of Britten et al. (1970). The mean nuclear DNA (nDNA) $\mathrm{G}+\mathrm{C}$ content from Metschnikowia strains was determined by thermal denaturation $\left(T_{\mathrm{m}}\right)$ (Marmur \& Doty, 1962) using a Gilford Response II Spectrophotometer and its thermal programming software. The $\mathrm{G}+\mathrm{C}$ content was determined at least twice for each strain in $0 \cdot 1 \times$ SSC (Owen et al., 1969). The extent of DNA relatedness was determined spectrophotometrically as described by Seidler \& Mandel (1971) and modified by Kurtzman et al. (1980), using a Gilford Response II Spectrophotometer and its thermal kinetics program.

rDNA sequencing and sequence analysis. Methods for nDNA isolation, amplification by PCR of the $26 \mathrm{~S}$ rDNA domain D1/D2 and sequencing with the ABI TaqDyeDeoxy Terminator Cycle Sequencing kit and the ABI model 377 automated DNA sequencer (PE Biosystems) were previously described (Kurtzman \& Robnett, 1998). Sequence data were visually aligned with QEDIT 2.15 (SemWare, Marietta, GA, USA). Phylogenetic relationships were calculated with the maximum-parsimony program of PAUP ${ }^{\star} 4.0 \mathrm{~b} 3 \mathrm{a}$ (Swofford, 1998), as well as with the neighbour-joining program using the Kimura two-parameter distance measure. Schizosaccharomyces pombe was the designated outgroup species in all analyses.
Confidence limits for phylogenetic trees were estimated from bootstrap analysis (1000 replications). The nucleotide sequences for the new species reported here, as well as for reference species, have been deposited with GenBank under the accession numbers given in Fig. 3.

\section{RESULTS AND DISCUSSION}

\section{Latin diagnosis of Metschnikowia vanudenii Giménez-Jurado, Kurtzman \& Spencer-Martins sp. nov.}

In medio liquido cum dextroso et peptono et extracto levedinis post dies 3 ad $25^{\circ} \mathrm{C}$ cellulae sunt ovoideae aut cylindrateae $(3-5 \times 7-9 \mu \mathrm{m})$, binae vel in catenis brevis. Chlamydosporae praesentes plerumque, globosus $(6-8 \times 8-10 \mu \mathrm{m})$ refractivae. Reproductio vegetativae per gemmatae multipolarem et cellulae cruciformis formatur. Post dies 7 ad $25^{\circ} \mathrm{C}$ neque pseudohyphae nec hyphae formatur, sedimentum abundus. Cultura in medio agaro cum dextroso et peptono et extracto levedinis post dies 7 ad $25^{\circ} \mathrm{C}$ albida vel cremea butyrosa cum margine glabro. In agaro malti post dies 7 ad temperatura ambeunte, chlamydosporae globosus refractivae abundus et cellulae conjugationem tubi junctioniz formatur. In agaro farinae Zea mays post dies 7 ad $25^{\circ} \mathrm{C}$ pseudohyphae rudimentari formatur. Asci in agaro V8 dilutus post dies 12 ad $17^{\circ} \mathrm{C}$ ellipsoidopedunculati $(6-8 \times 25-45 \mu \mathrm{m})$, pedunculi cylindraci, 2-spori. Ascosporae aciculares vel filiformes. Fermentatio glucosum. Assimilat glucosum, sucrosum, maltosum,

Table 1. Origin and DNA base composition of the Metschnikowia strains examined

\begin{tabular}{|c|c|c|c|c|}
\hline Strain ${ }^{*}$ & Other designation $(s)^{*}$ & Isolation source & $\begin{array}{c}\mathrm{G}+\mathrm{C} \\
(\mathrm{mol} \%) \dagger\end{array}$ & $\begin{array}{c}\text { GenBank } \\
\text { no. }\end{array}$ \\
\hline \multicolumn{5}{|l|}{ M. lachancei } \\
\hline PYCC 5767 & SU(B) 99.220 .4 & $\begin{array}{l}\text { Flower of Calystegia sepium, Newfound Gap, } \\
\text { Smoky Mountains National Park, TN, USA }\end{array}$ & ND & AF313346 \\
\hline PYCC $4650^{\mathrm{T}}$ & $\begin{array}{l}\text { CBS } 9134^{\mathrm{T}}, \mathrm{UWO}(\mathrm{PS}) 86 \text { AW } 4.1^{\mathrm{T}} \text {, } \\
\text { NRRL Y-17036 }^{\mathrm{T}}\end{array}$ & $\begin{array}{l}\text { Muscoid fly plate of Asclepias syriaca, Ontario, } \\
\text { Canada }\end{array}$ & $44 \cdot 4 \pm 0 \cdot 6$ & AF017404 \\
\hline PYCC 4603 & UWO(PS) 87AD3.1, NRRL Y-27241 & Nectar of Asclepias syriaca, Québec, Canada & $43 \cdot 3 \pm 0 \cdot 2$ & \\
\hline PYCC 4606 & UWO(PS) 86A1.1 & Nectar of Asclepias syriaca, Québec, Canada & $43 \cdot 4 \pm 0 \cdot 2$ & \\
\hline PYCC 4648 & CBS 9132, UWO(PS) 86A2.1 & Nectar of Asclepias syriaca, Québec, Canada & $42 \cdot 7 \pm 0 \cdot 5$ & \\
\hline PYCC $4446^{\mathrm{T}}$ & CBS $5834^{\mathrm{T}}$, NRRL Y-7112 ${ }^{\mathrm{T}}$ & Flower of Epilobium angustifolium, Canada & $42 \cdot 8 \pm 0 \cdot 2$ & U44825 \\
\hline
\end{tabular}

ND, Not determined.

${ }^{*}$ CBS, Centraalbureau voor Schimmelcultures, Utrecht, The Netherlands; NRRL, Agricultural Research Service Culture Colllection, National Center for Agricultural Utilization Research, Peoria, IL, USA; PYCC, Portuguese Yeast Culture Collection, Centro de Recursos Microbiológicos (CREM), Universidade Nova de Lisboa, Monte de Caparica, Portugal; UWO, University of Western Ontario, Canada; SU, Syracuse University, NY, USA.

$\dagger$ DNA base composition determined by melting temperature $\left(T_{\mathrm{m}}\right)$, based on three or more determinations. 
L-sorbosum, cellobiosum (variabile), $\alpha, \alpha$-trehalosum (variabile), melezitosum, amylum solubile (variabile), D-xylosum (variabile), ethanolum (variabile), glycerolum (variabile), ribitolum (variabile), D-mannitolum (variabile), D-sorbitolum, salicinum (variabile), arbutinum, D-glucosaminum, glucono$\delta$-lactonum (variabile), D-glutamatum (variabile), $N$-acetylglucosaminum (variabile) et 2-ketogluconatum ad non D-galactosum, lactosum, melibiosum, raffinosum, inulinum, L-arabinosum, D-arabinosum, D-ribosum, L-rhamnosum, erythritolum, D-glucitolum, methyl- $\alpha$-D-glucosidum, acidum lacticum, acidum succinicum, acidum citricum, myo-inositolum, methanolum, acidum glucoronicum, acidum gluconicum, acidum tartaricum et acidum malicum. Assimilat L-lysini, ethylamini, cadaverini, D-glucosaminum (variabile), betanini, D-glutaminum ad non kallii nitratis, sodii nitrosi, creatino nec creatinino. Vitaminae externae ad crescentiam necessariae sunt. Crescit in $30^{\circ} \mathrm{C}$ sed non in $35^{\circ} \mathrm{C}$. Materia amyloidea non formatur. Ureum non finditur. Ubiquinonum majus Q-9. Proportio molaris guanini plus cytosini in acidi deoxyribonucleati $44 \cdot 4 \mathrm{~mol} \%$.

Typus: PYCC $4650^{\mathrm{T}}$, ex flore, exsicatus et vivus in collectione zymotica Centraalbureau voor Schimmelcultures (CBS $9134^{\mathrm{T}}$ ), Trajectum ad Rhenum, praeservatus.

\section{Description of Metschnikowia vanudenii Giménez-Jurado, Kurtzman \& Spencer-Martins sp. nov.}

Growth in glucose $(2 \%)$ yeast extract $(0.5 \%)$ peptone (1\%) broth. After 3 days at $25^{\circ} \mathrm{C}$, vegetative cells are ovoid to cylindrical $(3-5 \times 7-9 \mu \mathrm{m})$ and occur mostly in pairs, tetrads or in short chains. Some cells develop into characteristic 'aeroplane' or cross formations. Chlamydospores, when present, are globose to subglobose in shape $(6-8 \times 8-10 \mu \mathrm{m})$, highly refractile and contain several spherical lipid globules. Some strains produce few or no chlamydospores. No pseudohyphae or hyphae were observed in this medium. Cell division occurs by multilateral budding. After 1 week at $25^{\circ} \mathrm{C}$, abundant sediment is formed.

Growth on glucose (2\%) yeast extract $(0.5 \%)$ peptone (1\%) agar. After 1 week at room temperature, strains form white to cream, smooth to papillate, glossy, butyrous colonies with entire margins.

Growth on malt extract agar. After 1 week at room temperature, strains form copious amounts of subglobose chlamydospores with large, easily seen oil droplets. Cross or 'aeroplane' configurations are present in strains PYCC 4606, PYCC 4648 and PYCC $4650^{\mathrm{T}}$.

Dalmau plate cultures on corn-meal agar. After 1 week at $25^{\circ} \mathrm{C}$, growth under semi-anaerobic conditions showed development of primitive pseudohyphae.

Formation of ascospores. Asci with ascospores were formed by PYCC $4650^{\mathrm{T}}$ after incubation for 12 days at

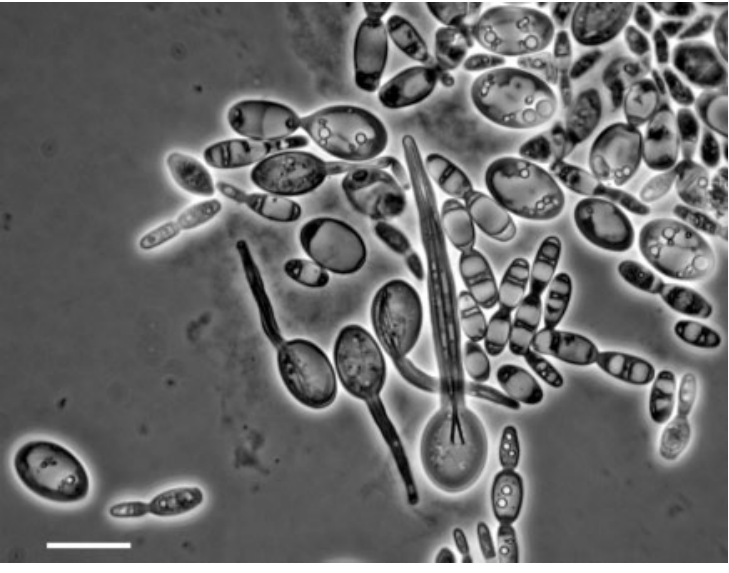

Fig. 1. Phase-contrast photomicrographs of $M$. vanudenii PYCC $4650^{\top}$ grown on dilute V8 agar at $17^{\circ} \mathrm{C}$. Mature ascus containing two filiform ascospores. Scale bar, $10 \mu \mathrm{m}$.

$17^{\circ} \mathrm{C}$ on dilute (1:15) V8 agar (Fig. 1). Asci initially developed from ellipsoid chlamydospores, which further elongated resulting in a cylindrical peduncle shape. Mature asci $(6-8 \times 25-45 \mu \mathrm{m})$ contain two acicular to filiform ascospores, which are noticeably pointed at one end. Most asci are persistent, although a few become deliquescent.

Ascosporulation was not observed for strains PYCC 4603, PYCC 4606, PYCC 4648 and PYCC 4649. These four strains were mixed pairwise in all possible combinations with just one pair, PYCC $4648 \times$ PYCC 4649 , showing evidence of mating. Conjugated cells and apparent zygotes were observed, but ascospores were not seen. Additionally, when this pair of strains was mixed, the frequency of cross-like cells markedly increased over that seen for the individual strains. The observation of conjugants suggests that $M$. vanudenii might be heterothallic with haploid strains showing varying degrees of mating competence.

\section{Physiological and biochemical characteristics}

See Table 2.

Etymology. The specific epithet vanudenii, Latin gen. of van Uden, was chosen in honour of the late Professor Nicolau van Uden for his important contributions to the study of the yeast genus Metschnikowia as well as for his work on the physiology and biochemistry of yeasts.

Origin and deposits. The type strain PYCC $4650^{\mathrm{T}}$ [UWO(PS) 86AW4.1] was isolated from a 'walk plate' sampling of a muscoid fly collected from the common milkweed Asclepias syriaca in Guelph, Ontario, Canada. This strain has been deposited (living and dried) in the Portuguese Yeast Culture Collection (PYCC), Centro de Recursos Microbiológicos (CREM), Universidade Nova de Lisboa, Caparica, Portugal, and under number CBS 9134 
Table 2. Physiological and biochemical characteristics that differentiate $M$. lachancei sp. nov. from $M$. vanudenii sp. nov.

Species: M. lachancei strains PYCC $4605^{\mathrm{T}}$ and PYCC 5767; M. vanudenii strains PYCC $4650^{\mathrm{T}}$, PYCC 4603, PYCC 4606, PYCC 4648 and PYCC 4649. All strains tested positive for glucose fermentation. Glucose, sucrose, maltose, arbutin, melezitose and xylitol were assimilated by all strains, but D-ribose, L-arabinose, D-arabinose, L-rhamnose, methyl- $\alpha$-D-glucoside, melibiose, lactose, raffinose, inulin, starch, $m$-erythritol, galactitol, $m$-inositol, D-glucuronic, DL-lactic acid, citric acid, malic acid, L-tartaric acid and methanol were not. Ethylamine, cadaverine and betaine, as sole nitrogen sources, were assimilated by all strains, but nitrate, nitrite, creatine and creatinine were not. All strains were able to grow in vitaminfree medium, $50 \%$ glucose, $10 \% \mathrm{NaCl} / 5 \%$ glucose and at $30{ }^{\circ} \mathrm{C}$, but were not able to grow in $\mathrm{YNB}$ with $0.01 \%$ cycloheximide and at $35^{\circ} \mathrm{C}$. None formed starch-like compounds. Abbreviations: w, weak; $\mathrm{V}$, variable; +, positive; -, negative.

\begin{tabular}{|c|c|c|}
\hline Characteristic & M. lachancei & M. vanudenii \\
\hline \multicolumn{3}{|l|}{ Assimilation of carbon compounds: } \\
\hline D-Galactose & + & $-/ \mathrm{W}$ \\
\hline L-Sorbose & $\mathrm{W}$ & $\mathrm{V}$ \\
\hline D-Glucosamine & $\mathrm{W}$ & $\mathrm{v}$ \\
\hline D-Xylose & + & $\mathrm{V}$ \\
\hline$\alpha, \alpha$-Trehalose & + & $\mathrm{v}$ \\
\hline Cellobiose & + & $\mathrm{V}$ \\
\hline Salicin & + & $\mathrm{v}$ \\
\hline Glycerol & - & $\mathrm{V}$ \\
\hline Ribitol & $\mathrm{W}$ & $\mathrm{V}$ \\
\hline D-Glucitol & - & $\mathrm{V}$ \\
\hline D-Mannitol & + & $\mathrm{v}$ \\
\hline D-Glucono-1,5-lactone & + & $\mathrm{V}$ \\
\hline 2-Keto-D-gluconic acid & + & $\mathrm{v}$ \\
\hline D-Gluconic acid & + & $\mathrm{V}$ \\
\hline Succinic acid & $\mathrm{W}$ & - \\
\hline Ethanol & - & $\mathrm{V}$ \\
\hline$N$-Acetyl-D-glucosamine & + & $\mathrm{v}$ \\
\hline \multicolumn{3}{|l|}{ Assimilation of nitrogen compounds: } \\
\hline D-Glucosamine & - & $\mathrm{v}$ \\
\hline L-Glutamic acid & + & $\mathrm{V}$ \\
\hline \multicolumn{3}{|l|}{ Lipolytic activity: } \\
\hline Tween 80 & $\mathrm{~V}$ & - \\
\hline \multicolumn{3}{|l|}{ Other: } \\
\hline Hydrolysis of urea & + & - \\
\hline nDNA G + C content $(\mathrm{mol} \%)$ & $46 \cdot 9 \pm 0 \cdot 4\left(\mathrm{PYCC} 4605^{\mathrm{T}}\right)$ & $44 \cdot 4 \pm 0 \cdot 6\left(\mathrm{PYCC} 4650^{\mathrm{T}}\right)$ \\
\hline
\end{tabular}

in the Centraalbureau voor Schimmelcultures in Utrecht, The Netherlands.

\section{Latin diagnosis of Metschnikowia lachancei Giménez-Jurado, Kurtzman, Starmer \& Spencer- Martins sp. nov.}

In medio liquido cum dextroso et peptono et extracto levedinis post dies 3 ad $25^{\circ} \mathrm{C}$ cellulae sunt ellipsoideae aut cylindrateae $(3-7 \times 8-3 \mu \mathrm{m})$, singulae, binae vel aggregatae, gemmationem multipolarem reproducentes. Breves pseudohyphae formatur. Chlamydosporae non formatur. Post dies 7 ad $25^{\circ} \mathrm{C}$ sedimentum parcum formatur. Cultura in medio agaro cum dextroso et peptono et extracto levedinis post dies 7 , albida vel cremea cum margo crenatus. In agaro farinae Zea mays post dies 7 ad $25^{\circ} \mathrm{C}$ pseudohyphae vera cum conidia globosa formatur. In agaro $V 8$ dilutus post dies $3-4$ ad $17^{\circ} \mathrm{C}$ asci clavatispedunculati, pedunculi cylindrateae $(3-6 \times 14-$ $23 \mu \mathrm{m}), 2$-spori in quoque asco. Ascosporae clavatus vel pyriformis. Fermentatio glucosum. Assimilat glucosum, D-galactosum, D-glucosaminum, D-xylosum, sucrosum, maltosum, $\alpha, \alpha$-trehalosum, cellobiosum, salicinum, arbutinum, melezitosum, glycerolum, xylitolum, D-sorbitolum, D-mannitolum, glucono- $\delta$-lactonum, 2-ketogluconatum, acidum gluconicum, D-glutamatum et $\mathrm{N}$-acetyl-glucosaminum, et ad non L-sorbosum, D-ribosum, L-arabinosum, D-arabinosum, L-rhamnosum, ethanolum, methanolum, methyl- $\alpha$-Dglucosidum, melibiosum, lactosum, raffinosum, inulinum, amylum solubile, erythritolum, ribitolum, D-glucitolum, myoinositolum, acidum glucoronicum, acidum lacticum, acidum 
succinicum, acidum citricum, acidum malicum et acidum tartaricum. Assimilat L-lysini, ethylamini, cadaverini, betanini, D-glutaminum ad non kallii nitratis, sodii nitrosi, D-glucosaminum, creatino nec creatinino. Vitaminae externae ad crescentiam necessariae sunt. Crescit in $30^{\circ} \mathrm{C}$ sed non in $35^{\circ} \mathrm{C}$. Materiae amyloidea non formatur. Ureum finditur. Ubiquinonum majus Q-9. Proportio molaris guanini plus cytosini in acidi deoxyribonucleati $46 \cdot 9 \mathrm{~mol} \%$.

Typus: PYCC $4605^{\mathrm{T}}$, ex flore, in collectione zymotica Centraalbureau voor Schimmelcultures (CBS 9131 $1^{\mathrm{T}}$ ), Trajectum ad Rhenum, praeservatus.

\section{Description of Metschnikowia lachancei Giménez-Jurado, Kurtzman, Starmer \& Spencer- Martins sp. nov.}

Growth in glucose $(2 \%)$ yeast extract $(0.5 \%)$ peptone (1\%) broth. After 3 days at $25^{\circ} \mathrm{C}$, vegetative cells are ellipsoidal to cylindrical $(3-7 \times 8-13 \mu \mathrm{m})$ and occur in pairs, tetrads or small chains. Cell division occurs by multilateral budding. Sparse slender pseudohyphae are formed. Chlamydospores are not formed. Some cells contain refractile globules. After 1 week at $25^{\circ} \mathrm{C}$ sediment is formed.

Growth on glucose (2\%) yeast extract (0.5\%) peptone $(1 \%)$ agar. After 1 week at room temperature, the streak culture is cream to off-white coloured, smooth, glossy and with a lobate margin.

Dalmau plate cultures on corn-meal agar. After 1 week at $25^{\circ} \mathrm{C}$, growth under semi-anaerobic conditions shows the presence of slender pseudohyphae. Cells become elongated and eventually form branching pseudohyphae with terminal spherical conidia. Branching occurs from the quadrants of the parent cell with secondary branching occurring quite often. No crosswalls form between hyphal cells.

Formation of ascospores. Asci with ascospores were observed in cultures of PYCC $4605^{\mathrm{T}}$ after 3-4 days incubation at $17^{\circ} \mathrm{C}$ in dilute $(1: 15) \mathrm{V} 8$ agar medium. Asci are clavate in shape and develop directly from vegetative cells. Some asci develop directly after conjugation of two cells followed by differentiation at one end of the conjugant giving rise to a long cylindrical peduncle. Mature asci $(3-6 \times 14-3 \mu \mathrm{m})$ usually contain two spindle-shaped ascospores, side by side, with their pointed ends oriented towards the peduncle or elongated portion of the ascus (Fig. 2), but occasionally asci with one protruding ascospore are observed. Asci occur either in pairs or groups of short chains, show different stages of development and are usually persistent. Older asci show ascospores with swollen ends containing visible vacuolar and lipidic material. No ascospores were observed in strain PYCC 5767.

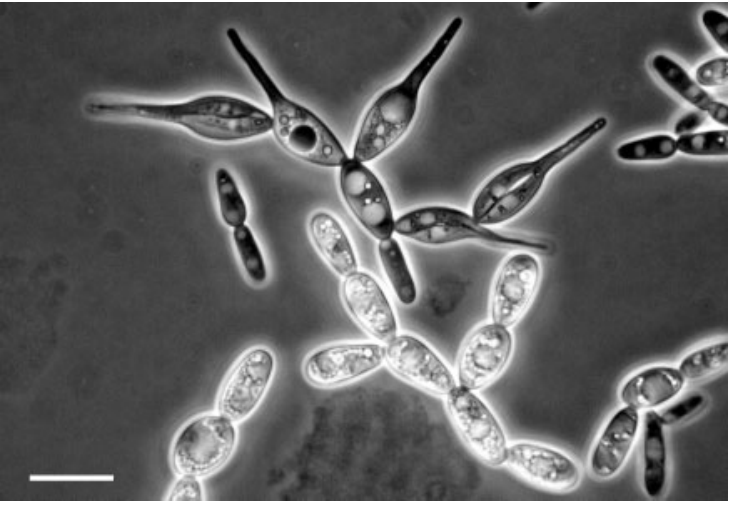

Fig. 2. Phase-contrast photomicrograph of $M$. lachancei PYCC $4605^{\top}$. Formation of asci containing clavate ascospores, after 1 week at $17^{\circ} \mathrm{C}$ in dilute $(1: 14) \mathrm{V} 8$ agar. Scale bar, $10 \mu \mathrm{m}$.

\section{Physiological and biochemical characteristics}

See Table 2.

Etymology. The specific epithet lachancei, Latin gen. of Lachance, was chosen in honour of Professor Marc-André Lachance, in recognition of his important contribution to yeast taxonomy and the discovery of exotic species of the yeast genus Metschnikowia.

Origin and deposits. The type strain PYCC $4605^{\mathrm{T}}$ $\left[=\mathrm{UWO}(\mathrm{PS}) 7 \mathrm{ASB} 2.3^{\mathrm{T}}\right]$ was isolated from nectar of the flower Asclepias syriaca in South Bombay, NY, USA. This strain has been deposited (living and dried) in the PYCC CREM, Universidade Nova de Lisboa, Caparica, Portugal, and under number CBS 9131 in the Centraalbureau voor Schimmelcultures, Utrecht, The Netherlands.

Table 3. DNA relatedness (\%) among isolates of $M$. vanudenii and $M$. lachancei and the type strains of $M$. gruessii and $M$. reukaufii

Strains: 1, M. vanudenii PYCC $4650^{\mathrm{T}} ; 2$, M. vanudenii PYCC 4649; 3, M. vanudenii PYCC 4648; 4, M. vanudenii PYCC 4606; 5, M. vanudenii PYCC 4603; 6, M. lachancei PYCC $4605^{\mathrm{T}} ; 7, \mathrm{M}$. gruessii PYCC $4382^{\mathrm{T}} ; 8$, M. reukaufii PYCC $4446^{\mathrm{T}}$. Data are means of two or more determinations. ND, Not determined.

\begin{tabular}{|lcrrrrrrr|}
\hline Strains & $\mathbf{1}$ & $\mathbf{2}$ & $\mathbf{3}$ & $\mathbf{4}$ & $\mathbf{5}$ & $\mathbf{6}$ & $\mathbf{7}$ & $\mathbf{8}$ \\
\hline $\mathbf{1}$ & 100 & 85 & 100 & 94 & $\mathrm{ND}$ & 0 & 2 & 19 \\
$\mathbf{2}$ & & 100 & 88 & 90 & $\mathrm{ND}$ & 7 & 4 & 21 \\
$\mathbf{3}$ & & & 100 & $\mathrm{ND}$ & $\mathrm{ND}$ & $\mathrm{ND}$ & 7 & 30 \\
$\mathbf{4}$ & & & & 100 & 76 & $\mathrm{ND}$ & 0 & 3 \\
$\mathbf{5}$ & & & & & 100 & $\mathrm{ND}$ & 1 & 0 \\
$\mathbf{6}$ & & & & & & 100 & 12 & 23 \\
\hline
\end{tabular}




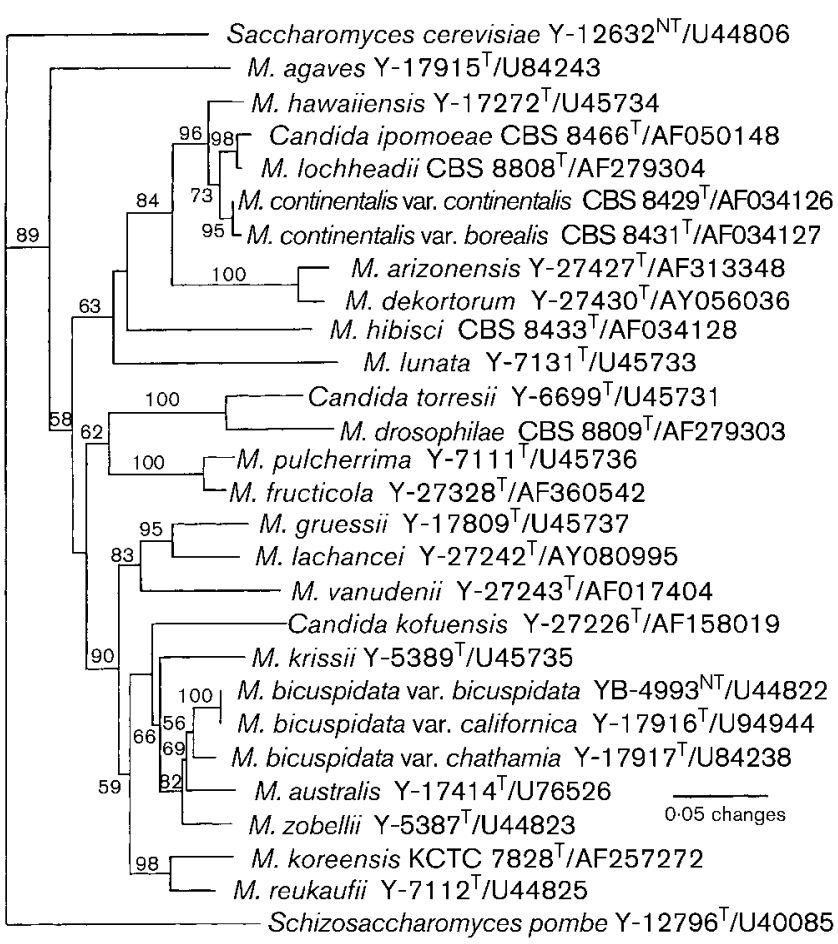

Fig. 3. Neighbour-joining tree with the Kimura two-parameter distance correction showing phylogenetic placement of $M$. vanudenii and $M$. lachancei among species of the genus Metschnikowia, related Candida species and reference species Saccharomyces cerevisiae and Schizosaccharomyces pombe (outgroup species in the analysis). Bootstrap values (1000 replications) are given for nodes with $>50 \%$ support. T, Type strain; NT, neotype strain. Culture collection prefixes: $Y$ and $Y B$, ARS Culture Collection (NRRL); CBS, Centraalbureau voor Schimmelcultures; KCTC, Korean Collection for Type Cultures.

\section{$G+C$ content and nDNA relatedness}

Initial characterization of the two new species was from mol\% G $+\mathrm{C}$ content, which revealed that they separated into two groups, $M$. lachancei with $46.9 \mathrm{~mol} \%$ and $M$. vanudenii with a strain mean of $43.5 \mathrm{~mol} \%$. This latter value is similar to the $\mathrm{G}+\mathrm{C}$ content of $M$. reukaufii (Table 1 ). nDNA reassociation experiments demonstrated $M$. vanudenii, M. lachancei and M. gruessii to be separate species (Table 3), which is consistent with relationships determined from rDNA sequence analysis (Fig. 3).

\section{Phylogeny}

Phylogenetic analysis of the D1/D2 domain of the large subunit rDNA revealed that $M$. vanudenii and $M$. lachancei fit within the Metschnikowia clade (Fig. 3). The two new species form a distinct lineage with $M$. gruessii and cluster with those members of Metschnikowia that produce small ascospores.

\section{ACKNOWLEDGEMENTS}

We thank Christie J. Robnett for determining the D1/D2 26S rDNA sequences for the two new species.

\section{REFERENCES}

Britten, R. J., Pavich, M. \& Smith, J. (1970). A new method of DNA purification. Carnegie Inst Wash Year Book 68, 400-402.

Hong, S. G., Chun, J., Oh, H. W. \& Bae, K. S. (2001). Metschnikowia koreensis sp. nov., a novel yeast species isolated from flowers in Korea. Int J Syst Evol Microbiol 51, 1927-1931.

Kurtzman, C. P. \& Droby, S. (2001). Metschnikowia fructicola, a new ascosporic yeast with potential for biocontrol of postharvest fruit rots. Syst Appl Microbiol 24, 395-399.

Kurtzman, C. P. \& Robnett, C. J. (1998). Identification and phylogeny of ascomycetous yeasts from analysis of nuclear large subunit (26S) ribosomal DNA partial sequences. Antonie van Leeuwenhoek 73, 331-371.

Kurtzman, C. P., Smiley, M. J., Johnson, C. J., Wickerham, L. J. \& Fuson, G. B. (1980). Two closely related heterothallic species, Pichia amylophila and Pichia mississipiensis: characterisation by hybridisation and deoxyribonucleic acid reassociation. Int J Syst Bacteriol 30, 208-216.

Lachance, M. A. \& Bowles, J. M. (2002). Metschnikowia arizonensis and Metschnikowia dekortorum, two new large-spored yeast species associated with floricolous beetles. FEMS Yeast Res 2, 81-86.

Lachance, M. A., Bowles, J. M., Kwon, S., Marinoni, G., Starmer, W. T. \& Janzen, D. H. (2001a). Metschnikowia lochheadii and Metschnikowia drosophilae, two new yeast species isolated from insects associated with flowers. Can J Microbiol 47, 103-109.

Lachance, M. A., Starmer, W. T., Rosa, C. A., Bowles, J. M., Barker, J. S. \& Janzen, D. H. (2001b). Biogeography of the yeasts of ephemeral flowers and their insects. FEMS Yeast Res 1, 1-8.

Marmur, J. \& Doty, P. (1962). Determination of the base composition of DNA from its thermal denaturation temperature. J Mol Biol 5, 109-118.

Owen, R. J., Hill, L. R. \& Lapage, S. P. (1969). Determination of DNA base compositions from melting profiles in dilute buffers. Biopolymers 7, 503-516.

Pitt, J. I. \& Miller, M. W. (1968). Sporulation in Candida pulcherrima, Candida reukaufi, and Chlamydozyma species and their relationship with Metschnikowia. Mycologia 60, 663-685.

Seidler, R. J. \& Mandel, M. (1971). Quantitative aspects of deoxyribonucleic acid renaturation: base composition, site of chromosome replication and polynucleotide homologies. J Bacteriol 106, 608-614.

Swofford, D. L. (1998). PAUP ${ }^{\star} 4.0$ : Phylogenetic analysis using parsimony. Sunderland, MA: Sinauer Associates.

Yarrow, D. (1998). Methods for the isolation, maintenance and identification of yeasts. In The Yeasts - a Taxonomic Study, 4th edn, pp. 77-100. Edited by C. P. Kurtzman \& J. W. Fell. Amsterdam: Elsevier. 